\title{
Analysis of Abstracts from the Medical Theses Written in Macedonian Language and Proposal of Standards for Abstract Preparation
}

\author{
Mirko Spiroski ${ }^{*}$ \\ Faculty of Medicine, Ss Cyril and Methodius University of Skopje, Skopje, Republic of Macedonia
}

\begin{abstract}
Citation: Spiroski M. Analysis of Abstracts from the Medical Theses Written in Macedonian Language and Proposal of Standards for Abstract Preparation. OA Maced J Med Sci. $2014 \quad$ Mar 15; 2(1):5-10. http://dx.doi.org/10.3889/oamjms.2014.001 Key words: medical science; PhD; MSc; Faculty of Medicine in Skopje, Republic of Macedonia.

"Correspondence: Prof. Dr. Mirko Spiroski. Faculty of Medicine, Ss Cyril and Methodius University of Skopje, 1109 Skopje, Republic of Macedonia.E-mail:mspiroski@yahoo.com

Received: 15-Jan-2014; Revised: 20-Feb2014; Accepted: 26-Feb-2014; Online first: 10-Mar-2014

Copyright: ๑ 2014 Spiroski. This is an openaccess article distributed under the terms of the Creative Commons Attribution License, which permits unrestricted use, distribution, and reproduction in any medium, provided the original author and source are credited.

Competing Interests: The authors have

declared that no competing interests exist.
\end{abstract}

\begin{abstract}
AIM: The aim of this study was to analyse abstracts from the medical theses written in Macedonian language and propose standards for abstract preparation.

MATERIAL AND METHODS: A total number of 97 English abstracts from the medical PhD theses and 122 Medical MSc theses defended at the Faculty of Medicine, Ss Cyril and Methodius University of Skopje, Republic of Macedonia in the period of 2007-2012 were analysed. Author definition, institution definition, language definition, deposition in the Central Medical Library, presence or absence of English abstracts, number of structured abstract, key words, and mentor declaration were analysed.

RESULTS: In the 97 Macedonian medical PhD theses (defended 2007-2012) author, institution or language were not defined. All PhD theses were deposited in the Central Medical Library. In $18.6 \%$ $\mathrm{PhD}$ theses, there was no English abstract, in $74.2 \%$ the abstracts were not structured, $36.1 \%$ of them were without key words, and $8.2 \%$ were without statement of the mentor. Similar findings were noticed in the 122 Macedonian medical MSc theses (defended 2007-2012) which did not have author, institution or language defined. Four percentages of MSc theses were not deposited in the Central Medical Library, 32.8\% MSc theses were submitted for defence without an English abstract, $65.6 \%$ MSc theses had no structured abstracts and $45.9 \%$ of them had no key words. Significant number of MSc theses (21.3\%) was submitted for defence without statement of the mentor and one medical MSc was retracted.
\end{abstract}

CONCLUSION: Standards for preparation English and Macedonian abstracts for medical PhD and MSc theses are proposed in order to increase their quality and international availability.

\section{Introduction}

\begin{abstract}
Doctoral dissertation is the highest achievement at the educational level in most countries of the world. In the Republic of Macedonia, process of preparation and defense of medical PhD theses can be divided in three different periods.
\end{abstract}

In the very beginning, the draft versions of the $\mathrm{PhD}$ theses were proposed by the author and submitted to the Scientific Board, reviewed by the commission consisting of three members and the final version was prepared. This last step, the preparation of the medical PhD thesis, was the sole responsibility of the author with very small, if any, support of the mentor of the dissertation and the institution where the author was affiliated. Completed PhD thesis was submitted for revision by the three members of the commission, and proposed for acceptance to the Scientific-Educational Board of the Medical Faculty in Skopje. The thesis was presented and defended publicly in front of five members of the commission.
The content of the medical PhD thesis was not allowed to be published during the preparation, nor after the defense. The printed copy of the medical $\mathrm{PhD}$ (written in Macedonian language, and deposited in the Central Medical Library and/or other libraries) was the only source for complete scientific information. The abstract written usually in English was the unique peace of scientific information for the non-Macedonian audience/scholars, but was insufficient to serve as a scientific source [1]. Macedonian medical $\mathrm{PhD}$ theses defended in that period were practically restricted to the use of Macedonian scientists only.

In the second period, significant changes were introduced aimed to increase the quality and availability of the medical PhD theses. The criterion of three published papers, one of which in the journal indexed in PubMed, was a prerequisite for the PhD to be accepted for review and for defence. The other steps were similar as in the previous period. Such policy has significantly increased the number of 
published papers by the Macedonian medical scientists indexed in PubMed [2] and Scopus [3].

The third period started in the year 2011 with the establishment of PhD School at the Ss Cyril and Methodius University of Skopje (UKIM) by organized educational support for the authors, mentors and faculties as members of the UKIM. The first generation of $\mathrm{PhD}$ candidates is in the process of education and preparation of proposals. We shall see the results after the completion of the first generation (around 2014-2015 year).

Macedonian medical PhD theses are deposited in the Central Medical Library at the Faculty of Medicine, Ss Cyril and Methodius University of Skopje and are publicly available in a printed version. Unfortunately, there is neither available electronic form of the medical PhD theses nor repository of dissertations (individual or institutional). From time to time, some of the Macedonian medical PhD theses are published in their short versions or in a form of an abstract. Macedonian Journal of Medical Sciences published abstracts of Macedonian medical PhD [4-9] and MSc theses [10-15], starting from the year 2007. They are published as given in the theses themselves with the addition of the authors, titles, affiliations, dates of defence and mentors.

The aim of this study was to analyse abstracts from the medical theses written in Macedonian language and propose standards for abstract preparation.

\section{Material and Methods}

A total number of 97 English abstracts from the medical PhD theses and 122 medical MSc theses defended at the Faculty of Medicine, Ss Cyril and Methodius University of Skopje, Republic of Macedonia during the period of 2007-2012 were analysed. Author definition, institution definition, language definition, deposition in the Central Medical Library, presence or absence of English abstracts, number of structured abstracts, key words, and mentor declaration were analysed. Typical English abstract preparation of medical PhD thesis written in Macedonian language is shown in Fig. 1.

Based on the findings in this study, as well as on the international standards, standards for abstract preparation of the medical theses written in Macedonian language were suggested.

\section{MBSTRA CT}

The killer cell immunoglobulin-like receptors (KIR) are surtace molecules important for regubtion of the adtivity of natural foller (NK) cells and some subsets of cells. They ad through interacuon with ligands found on target cells producing activating or inhibtory signal. An extensive diversty exists in the KIR gene lodus. In this $\mathrm{PhD}$ thesi we have set an am to determine the KIR gene and genotype frequencies in dfferem populations from Republic of Macedoria and to analyee eventual associations (both positive and negative) between certain KIR genes genotypes and selected diseases.

Total of 421 DNA samples from unrelated wolunteer healthy donors fom the Macedonian hurran DNA bank (214 Macedonians, 104 Abanians and 103 Romal 6 patierts wolunteer donors of bone marrow were analyeed.

Al the 16 KR genes were determined in the Macedonian popuation, and total of 56 different KIR genotypes were genotyped in the Macedonian population, of which 14 new genotypes that were referred to the database wuw allelefequencies. net. The companison of KIR gene frequencies between Abanians and wacedonians living in and KIR2OS $4(\mathrm{p}=0050)$. Total of 45 different KIR genotypes were bund in the studied Abanian population, of which iwe new. The comparison of KIR gene tequencies between Roma and Macedonians rom Republic of Macedonia reveals statisticall significant difference for K.R $30 L 1(p=0.038)$ and KR2DSY $(p=0011)$. Talal of 3 different KIR genotypes were bund in the Romra population, of which sx were new. The comparison of KIR gene requencies between patients with $\mathrm{H} 1 \mathrm{~N} 1$ intection and healthy controls from Republic of Macedonia reveals statistically signiicant difference for K.YR2OL1 ( $\mathrm{F}=1$ in the patients group, and $\mathrm{F}=0994$ in the cortrols group, $\mathrm{p}=0 \mathrm{045}$ ). $\mathrm{Ac}$ much as 3 of the 4 patients with severe form of encephalitis caused by the Wiest Nile virus, had the same KR genotype ( $B \times 71$ ), while the fouth patient had genotype $B \times 89$. The comparison of KIR gene requencies between 63 haematogica paients and healthy Macedoniars reveas statistically sgnircant difference or the KIR3OL framework gene ( $F=1$ in the cortrol group, and $F=0.95$ in patients group, $p=0.001)$ when Kinas a o siancis signiicant difterence was found br the requencies of $8 \times 3$ and $8 \times 439$ both present more otten in the group of haenalogical patients then Bxe contol group ( $\mathrm{p}=0017$ and $\mathrm{p}=0.009$, respectively). When comparing the requences of the 16 analyeed KIR gene in the pairs patient-donor with 214 healthy Macedonians, a satistically significant
difference was found or Kur $20 S 1$ which was more requent in the group of sibling donors $(\mathrm{p}=0004)$, and especially requent in the subgroup of 13 donors form pairs where severe gratt versus host reaction was seen ( $(\mathrm{p}=0.002)$

These results may be used in anthropological studies, but can also be helpfu in clarication of the impact of the KIR molecules in the development andior progression of the viral infections, and their association with the hematological malignant diseases and the course of the transplantation of bone marrou.

Kemword's: KIR gene polymorphism, SSP genotyping, Macedonian population, Abania population, Forma population, H1N1 panderric influenza, Whest Nile encephalitis virus. association study, haermatological malignant disease, bone marrow transplantation, gra

Figure 1: Typical English abstract preparation of medical PhD thesis written in Macedonian language. Ask yourself: Who is the author? Where the dissertation was prepared?; Which language is written in?; Who is the mentor? There is no information about the basic questions.

\section{Results}

Abstracts in Macedonian medical PhD theses

In the 97 Macedonian medical PhD theses (defended 2007-2012) there was no definition of author, institution or language. All PhD theses were deposited in the Central Medical Library. In 18 (18.6\%) PhD theses there was no English abstract, in $72(74.2 \%)$ the abstracts were not structured, in 35 $(36.1 \%)$ there were no key words, and in $8(8.2 \%)$ there was no declaration of the mentor (Table 1).

Table 1: Analysis of different parts of abstracts in the Macedonian Medical PhD theses.

\begin{tabular}{|c|c|c|c|c|c|c|c|}
\hline & 2007 & 2008 & 2009 & 2010 & 2011 & 2012 & $2007-2012$ \\
\hline Number of PhD theses $(n)$ & 7 & 15 & 24 & 8 & 22 & 21 & 97 \\
\hline No author definition [n (\%)] & $7(100)$ & $15(100)$ & $24(100)$ & $8(100)$ & $22(100)$ & $21(100)$ & $97(100)$ \\
\hline No institution definition [n (\%)] & $7(100)$ & $15(100)$ & $24(100)$ & $8(100)$ & $22(100)$ & $21(100)$ & 97 (100) \\
\hline No language definition [n (\%)] & $7(100)$ & $15(100)$ & $24(100)$ & $8(100)$ & $22(100)$ & $21(100)$ & 97 (100) \\
\hline No deposition in $\mathrm{CML}^{*}$ [n (\%)] & $0(0)$ & $0(0)$ & $0(0)$ & $0(0)$ & $0(0)$ & $0(0)$ & $0(0)$ \\
\hline No abstract [n (\%)] & $1(14.3)$ & $5(33.3)$ & $6(25.0)$ & $0(0)$ & $2(9.1)$ & $4(19.0)$ & $18(18.6)$ \\
\hline No structured abstract [n (\%)] & $6(85.7)$ & $14(93.3)$ & $22(91.7)$ & $7(87.5)$ & $10(45.4)$ & $13(61.9)$ & $72(74.2)$ \\
\hline No Key Words [n (\%)] & $0(0)$ & $2(13.3)$ & $11(45.8)$ & $2(25.0)$ & $9(40.9)$ & $11(52.4)$ & $35(36.1)$ \\
\hline No mentor declaration [n (\%)] & $0(0)$ & $3(20.0)$ & $0(0)$ & $4(50.0)$ & $0(0)$ & $1(4.8)$ & $8(8.2)$ \\
\hline Reference & [4] & [5] & [6] & [7] & [8] & [9] & This paper \\
\hline
\end{tabular}




\section{Abstracts in Macedonian medical MSc theses}

Similar findings were noticed in the 122 Macedonian medical MSc theses (defended 20072012), which did not have author, institution or language definition. Five $(4.1 \%)$ theses were not deposited in the Central Medical Library. Forty $(32.8 \%)$ MSc theses were submitted for defence without an English abstract. Eighty (65.6\%) MSc theses were without structured abstracts and 56 $(45.9 \%)$ of them were without key words. Significant number of MSc theses [26 (21.3\%)] were submitted for defence without declaration of the mentor. One medical MSc was retracted ([A. Strezova. Genotyping of HLA-A, HLAC and HLA-B loci with Reverse Line Strip hybridization in Macedonian Population and association of HLA class I alleles with spondylitis (MSc thesis). Skopje, Republic of Macedonia: Institute of Immunobiology and Human Genetics, Faculty of Medicine, University “Ss Kiril and Metodij”; 2009.]) [16] (Table 2).

Table 2: Analysis of different parts of abstracts in the Medical MSc theses from the Republic of Macedonia.

\begin{tabular}{|c|c|c|c|c|c|c|c|}
\hline & 2007 & 2008 & 2009 & 2010 & 2011 & 2012 & $2007-2012$ \\
\hline Number of MSc theses $(n)$ & 20 & 26 & 30 & 13 & 23 & 10 & 122 \\
\hline No author definition [n (\%)] & $20(100)$ & $26(100)$ & $30(100)$ & $13(100)$ & $23(100)$ & $10(100)$ & $122(100)$ \\
\hline No institution definition [n (\%)] & $20(100)$ & $26(100)$ & $30(100)$ & $13(100)$ & $23(100)$ & $10(100)$ & $122(100)$ \\
\hline No language definition [n (\%)] & $20(100)$ & $26(100)$ & $30(100)$ & $13(100)$ & $23(100)$ & $10(100)$ & $122(100)$ \\
\hline No deposition in $\mathrm{CML}^{*}[\mathrm{n}(\%)]$ & $0(0)$ & $2(7.7)$ & 1 (3.3) & $0(0)$ & $2(8.7)$ & $0(0)$ & $5(4.1)$ \\
\hline No abstract [n (\%)] & $3(15.0)$ & $9(34.6)$ & $8(26.7)$ & $6(61.5)$ & $11(47.8)$ & $3(30.0)$ & $40(32.8)$ \\
\hline No structured abstract [n (\%)] & $18(90.0)$ & $20(76.9)$ & $8(26.7)$ & $13(100)$ & $17(73.0)$ & $4(40.0)$ & $80(65.6)$ \\
\hline No Key Words [n (\%)] & $7(35.0)$ & $12(46.1)$ & $14(46.7)$ & $9(69.3)$ & $11(47.8)$ & $3(30.0)$ & 56 (45.9) \\
\hline No mentor declaration [n (\%)] & $7(35.0)$ & 5 (19.2) & $2(6.7)^{*}$ & $5(38.5)$ & $7(30.4)$ & $0(0)$ & $26(21.3)$ \\
\hline Reference & [10] & [11] & [12] & [13] & [14] & [15] & This paper \\
\hline
\end{tabular}

I alleles with spondylitis (MSc thesis). Skopje, Republic of Macedonia: Institute of Immunobiology and Human Genetics, Faculty of Medicine, University "Ss Kiril and Metodij"; 2009.]) [16].

Proposal of standards for publication abstracts in the theses

Ten tasks were identified during the preparation, submission, defence, repository and publication of the medical theses.

Beside the $\mathrm{PhD}$ candidate of the dissertation, the responsible person in the Central Medical Library, the Vice-Dean for science, Ss Cyril and Methodius University of Skopje, as well as publishers are responsible for the quality of the different steps during preparation of dissertations (Table 3).

Table 3: Shared responsibilities during preparation of Medical theses in Republic of Macedonia.

\begin{tabular}{lll}
\hline \multicolumn{2}{|l}{ Task } & Primary Responsibility \\
\hline 1. & Writing of the theses & PhD or MSc candidate \\
\hline 2. & $\begin{array}{l}\text { Control of abstracts (Macedonian } \\
\text { and English) }\end{array}$ & $\begin{array}{l}\text { Responsible person in the Central } \\
\text { Medical Library }\end{array}$ \\
\hline 3. & $\begin{array}{l}\text { Individual control of all applied } \\
\text { guidelines }\end{array}$ & Mentor \\
\hline 4. & $\begin{array}{l}\text { General control of application of } \\
\text { guidelines }\end{array}$ & Vice-Dean for science \\
\hline 5. & $\begin{array}{l}\text { Guidelines for preparation of } \\
\text { dissertation }\end{array}$ & Vice-Dean for science \\
\hline 6. & Deposition of printed theses & $\begin{array}{l}\text { Responsible person in the Central } \\
\text { Medical Library }\end{array}$ \\
\hline 7. & Public defence of theses & Vice-Dean for science \\
\hline 8. & Deposition in individual repository & PhD or MSc candidate \\
\hline 9. & $\begin{array}{l}\text { Deposition in institutional } \\
\text { repository }\end{array}$ & $\begin{array}{l}\text { Ss Cyril and Methodius University of } \\
\text { Skopje }\end{array}$ \\
\hline 10. & $\begin{array}{l}\text { Printed and/or electronic } \\
\text { publication }\end{array}$ & Publisher \\
\hline
\end{tabular}

A proposal for the preparation of English abstracts in the medical PhD and MSc theses written in Macedonian language is given in Figure 2. Structure of the abstract text (background, aim, material and methods, results, and conclusion) can be modified depending on the fields and subfields of the dissertation to an eight-heading format (objective, design, setting, patients, intervention, main outcome measures, results, and conclusions for original articles). The number of the words in this part of the abstract should be standardised, usually 500 words, but not more that 1,500 words. Otherwise, the abstract should be classified as expanded abstract, brief report or similar [17].

\section{Discussion}

We present the bibliographic results of the English abstracts in Macedonian medical PhD theses (defended 2007-2012) where no definition of author, institution or language was found. There was no English abstract in $18.6 \% \mathrm{PhD}$ theses, the abstracts were not structured in $74.2 \%, 36.1 \%$ of them had no key words, and $8.2 \%$ had no declaration of the mentor. Similar findings were found in the 122 Macedonian medical MSc theses (defended 20072012), which did not have author, institution or language definition. Four percentages of MSc theses were not deposited in the Central Medical Library, $32.8 \%$ MSc theses were submitted for defence without an English abstract, $65.6 \%$ MSc theses were without structured abstracts and, $45.9 \%$ of them were without key words. Significant number of MSc theses $(21.3 \%)$ was submitted for defence without declaration of the mentor and one medical MSc was retracted.

The first PhD at the Faculty of Medicine in Skopje was defended on May 17, 1958 by Dr. Radovan Perchinkovski entitled "The role of electrophoresis in the cardiovascular diseases". The 


\begin{tabular}{|c|c|}
\hline Abstract & \\
\hline $\begin{array}{l}\text { Name and surname } \\
\text { (e-mail): }\end{array}$ & Aleksandar Petlichkovski (petlichkovski@yahoo.com) \\
\hline Title: & $\begin{array}{l}\text { Molecular analysis of polymorphisms of Killer immunoglobulin-like receptor genes and } \\
\text { alleles in Republic of Macedonia }\end{array}$ \\
\hline Affiliation: & $\begin{array}{l}\text { Institute of Immunobiology and Human Genetics, Medical Faculty, Ss Cyril and Methodius } \\
\text { University of Skopje, Skopje, Republic of Macedonia }\end{array}$ \\
\hline Language: & Macedonian \\
\hline Theses: & PhD \\
\hline Field, Subfield: & Medicine, Basic Medicine \\
\hline BACKGROUND: & $\begin{array}{l}\text { The killer cell immunoglobulin-like receptors (KIR) are surface molecules, which are important for } \\
\text { regulation of the activity of natural killer (NK) cells and some subsets of T cells. They act through } \\
\text { interaction with ligands found on target cells producing activating or inhibitory signal. An extensive } \\
\text { diversity exists in the KIR gene locus. }\end{array}$ \\
\hline AIM: & $\begin{array}{l}\text { In this } \mathrm{PhD} \text { thesis we have set an aim to determine the KIR gene and genotype frequencies in } \\
\text { different populations from Republic of Macedonia and to analyze eventual associations (both } \\
\text { positive and negative) between certain KIR genes/genotypes and selected diseases. }\end{array}$ \\
\hline $\begin{array}{l}\text { MATERIAL AND } \\
\text { METHODS: }\end{array}$ & $\begin{array}{l}\text { Total of } 421 \text { DNA samples from unrelated volunteer healthy donors from the Macedonian human } \\
\text { DNA bank ( } 214 \text { Macedonians, } 104 \text { Albanians and } 103 \text { Roma), } 63 \text { patients with confirmed infection } \\
\text { with H1N1 pandemic influenza virus, } 4 \text { patients infected with West Nile encephalitis virus and } 63 \\
\text { patients with haematological malignancy, and } 24 \text { volunteer donors of bone marrow were analyzed. }\end{array}$ \\
\hline RESULTS: & 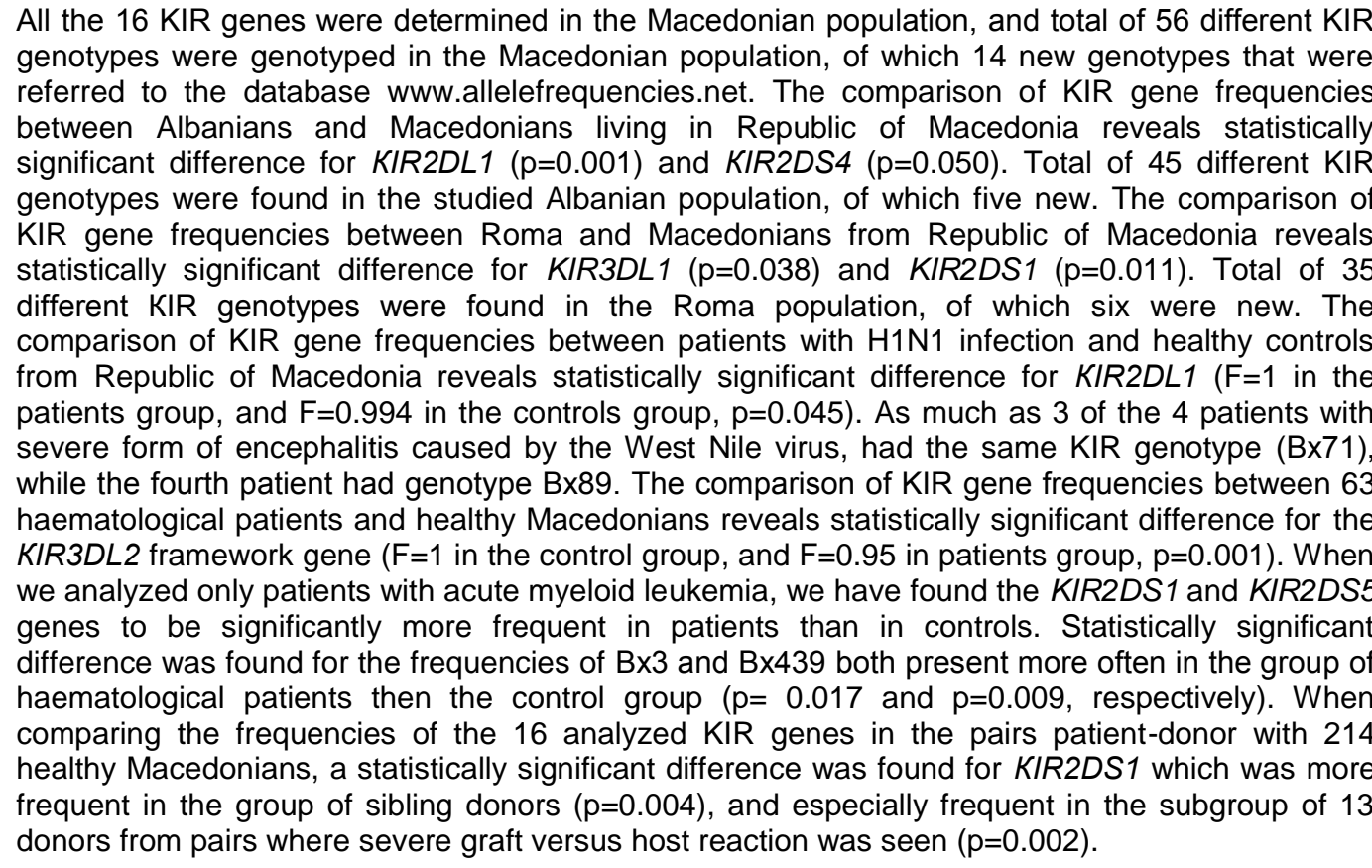 \\
\hline CONCLUSIONS: & $\begin{array}{l}\text { These results may be used in anthropological studies, but can also be helpful in clarification of the } \\
\text { impact of the KIR molecules in the development and/or progression of the viral infections, and their } \\
\text { association with the haematological malignant diseases and the course of the transplantation of } \\
\text { bone marrow. }\end{array}$ \\
\hline Key words: & $\begin{array}{l}\text { KIR gene polymorphism; SSP genotyping; Macedonian population; Albanian population; Roma } \\
\text { population; H1N1 pandemic influenza; West Nile encephalitis virus; association study, } \\
\text { haematological malignant disease; bone marrow transplantation; graft versus host reaction, } \\
\text { Republic of Macedonia. }\end{array}$ \\
\hline Defended: & October 17, 2013. \\
\hline Mentor (e-mail): & $\begin{array}{l}\text { Prof. Dr. Mirko Spiroski, Institute of Immunobiology and Human Genetics, Medical Faculty, Ss Cyril } \\
\text { and Methodius University of Skopje, Skopje, Republic of Macedonia (mspiroski@yahoo.com) }\end{array}$ \\
\hline Link: & http://www.???.pdf \\
\hline
\end{tabular}

Figure 2: Proposal of standards for abstract preparation of medical PhD and MSc theses written in Macedonian language. 
first PhD defended outside the Faculty of Medicine in Skopje was "Adsorpitional characteristics of alkaloids and hydration effects of alakaloids (morphine, codeine, thebaine and papaverine) on macromolecular systems in electrical and resorbtion field at different $\mathrm{pH}$ values" by Nada Chumbelikj (Belgrade: Faculty of Pharmacy, 1965). The first Master of Science (MSc) thesis at the Faculty of Medicine in Skopje was defended on November 18, 1976 by Dr. Katica Zafirovska entitled "Balance of liquids and electrolytes in renal insufficiency". The first Master of Science thesis defended outside the Faculty of Medicine in Skopje was "Toxicological effect of hydrargirum in the machineries of electrolysis" by $\mathrm{Dr}$. Vladimir Cvetanov (Zagreb: Faculty of Medicine, March 17, 1970) [18].

In 1973 postgraduate studies were introduced at the Faculty of Medicine in Skopje in order to transfer more profound knowledge to the medical students from different branches of medicine. After completing their studies and given a public elaboration of their thesis, the students acquired the title Master of Sciences (MSc) in medicine. If in the first 40 years this title was attained by 55 candidates, 50 years later MSc was attained by 112 doctors. In 2003 postgraduate studies in public health were introduced at the Faculty of Medicine [18].

In 1987 the Ad Hoc Working Group for Critical Appraisal of the Medical Literature, under the leadership of Dr. R. Brian Haynes, McMaster University, Hamilton, Ont., proposed a system for making more informative abstracts of clinical trials [19]. To assist clinicians in quickly finding articles that are both scientifically sound and applicable to their practices, the Ad Hoc Working Group for Critical Appraisal of the Medical Literature proposed, in 1987, a seven heading format for informative abstracts in clinical articles $[19,20]$. Accepting Altman's proposal [21], Haynes et al., in 1990, revised the format and content requirements for structured abstracts to an eight-heading format (objective, design, setting, patients, intervention, main outcome measures, results, and conclusions for original articles) [22]. In 1993, the International Committee of Medical Journal Editors (the so-called "Vancouver group") recommended use of structured abstracts in the "Uniform Requirements for Journals Submitted to Biomedical Journals" [23]. Following these proposals, medical journals in Europe and the United States have tried to provide more informative abstracts for articles of clinical interest.

Several authors published results of structured abstracts analysis in biomedical papers. One study examined the occurrence of structured abstracts in MEDLINE from March 1989 to December 1991. The study revealed that the number of structured abstracts in MEDLINE and the number of MEDLINE journals publishing structured abstracts increased substantially between 1989 and 1991. On average, articles with structured abstracts had more access points (Medical Subject Heading [MeSH $®$ ] terms and text words) than MEDLINE articles as a whole [24]. Both the number of individual records with structured abstracts and the number of journals publishing structured abstracts has increased steadily since 1991. Structured abstracts appeared in 20.3\% of the 580,583 articles indexed for MEDLINE in 2005, and the upward trend was continuing (23.0\% in 2008). More than 1,000 journals have continuously published structured abstracts (starting in one year after the proposal and continuing through 2005) in contrast to only 10 journals in 1989-1991 [25]. The top thirty journals according to impact factors noted in the "Medicine, General and Internal" category of the ISI Journal Citation Reports (2000) were sampled. Among 304 original articles that included abstracts, $188(61.8 \%)$ had structured and $116(38.2 \%)$ had unstructured abstracts. One hundred twenty-five $(66.5 \%)$ of the abstracts used the introduction, methods, results, and discussion (IMRAD) format, and $63(33.5 \%)$ used the 8-heading format proposed by Haynes et al. Twenty-one journals requested structured abstracts in their instructions to authors; 8 journals requested the 8-heading format; and 1 journal requested it only for intervention studies [26]. Another study evaluated the use of machine learning techniques in the classification of sentence type. A total of 7253 structured abstracts and 204 unstructured abstracts of Randomized Controlled Trials from MEDLINE were parsed into sentences and each sentence was labelled as one of four types (Introduction, Method, Result, or Conclusion). Support Vector Machine (SVM) and Linear Classifier models were generated and evaluated on cross-validated data. They concluded that classification of sentence type seems feasible within the domain of randomized control trials. Identification of sentence types may be helpful for providing context to end-users or other text summarization techniques [27].

The paper "How to Write an Abstract That Will Be Accepted for Presentation at a National Meeting" discusses the steps and offers suggestions for writing each of the abstract's components (title, author list, introduction, methods, results, and conclusions); considers the advantages and disadvantages of incorporating a table or figure into the abstract; offers several general writing tips; and provides annotated examples of well-prepared abstracts: one from an original study, one from a method/device evaluation, and one from a case report [28]. The evaluation of abstracts for scientific meetings has been shown to suffer from poor inter observer reliability. A measure was developed to assess the formal quality of abstract submissions in a standardized way. A quality index was developed for the evaluation of scientific meeting abstracts which was shown to be reliable, valid and useful [29]. It would be very useful to introduce quality 
index for the evaluation of $\mathrm{PhD}$ theses abstracts similar to the previous one.

The best solution for international availability and visibility of the medical $\mathrm{PhD}$ theses prepared and defended at the Faculty of Medicine in Skopje is to prepare them in English with Macedonian abstract, but the tradition and the Law on High Education restrict their preparation in Macedonian language. Electronic version of the medical $\mathrm{PhD}$ theses deposited either in the Individual repositories of $\mathrm{PhD}$ or in Institutional repository at the Medical Faculty or UKIM will force the standardisation not only of the elements of the English abstracts, but also of the other parts of the dissertations.

In conclusion, it can be emphasised that the English abstracts in Macedonian medical PhD and MSc theses, written in Macedonian, do not fulfil bibliographic and international criteria. It is necessary to propose and to include all bibliographic data in the English abstracts of the Macedonian medical theses necessary for international visibility.

\section{Acknowledgements}

The author would like to thank Central Medical Library for the cooperation about the availability of theses for analysis. The author is thankful to Dr. Slavica Hristomanova and Dr. Meri Kirijas (MD, PhD candidates) from the Institute of Immunobiology and Human Genetics, Faculty of Medicine, Ss Cyril and Methodius of Skopje for the preparation of $\mathrm{PhD}$ theses for publishing in Macedonian Journal of Medical Sciences.

\section{References}

1. Cals JW, Kotz D. Effective writing and publishing scientific papers, part II: title and abstract. J Clin Epidemiol. 2013;66(6):585

2. Spiroski M. Semantic Analysis of Macedonian Medical Abstracts Indexed in the PubMed Database using GoPubMed. Maced J Med Sci. 2013; 6(2):135-140.

3. Spiroski M. Analysis of Macedonian Medical Scientific Papers in the Scopus Database. Maced J Med Sci. 2013; 6(1):5-10.

4. Macedonian Medical Doctor of Philosophy (PhD) Theses Defended in 2007. Maced J Med Sci. 2008; 1(2):75-81.

5. Macedonian Medical Doctor of Philosophy $(\mathrm{PhD})$ Theses Defended in 2008. Maced J Med Sci. 2009; 2(2):165-176.

6. Macedonian Medical Doctor of Philosophy (PhD) Theses Defended in 2009. Maced J Med Sci. 2010; 3(1):70-88.

7. Macedonian Journal of Medical Sciences. Macedonian Medical Doctor of Philosophy (PhD) Theses Defended in 2010 Maced J Med Sci. 2011; 4(1):104-113.

8. Macedonian Journal of Medical Sciences. Macedonian Medical Doctor of Philosophy (PhD) Theses Defended in 2011. Maced J Med Sci. 2012; 5(1):114-134.

9. Macedonian Journal of Medical Sciences. Macedonian Medical Doctor of Philosophy (PhD) Theses Defended in 2012. Maced J Med Sci. 2013; 6(1):106-123.

10. Macedonian Medical Master of Science (MSc) Theses
Defended in 2007. Maced J Med Sci. 2008; 1(2):64-74.

11. Macedonian Medical Master of Science (MSc) Theses Defended in 2008. Maced J Med Sci. 2009; 2(1):79-91.

12. Macedonian Journal of Medical Sciences. Macedonian Medical Master of Science (MSc) Theses Defended in 2009. Maced J Med Sci. 2010; 3(2):192-209.

13. Macedonian Journal of Medical Sciences. Macedonian Medical Master of Science (MSc) Theses Defended in 2010. Maced J Med Sci. 2011; 4(2):210-215.

14. Macedonian Journal of Medical Sciences. Macedonian Medical Master of Science Theses Defended in 2011. Maced J Med Sci. 2012; 5(4):472-481.

15. Macedonian Journal of Medical Sciences. Macedonian Medical Master of Science (MSc) Theses Defended in 2012. Maced J Med Sci. 2013; 6(2):202-207.

16. Spiroski M. Retraction: Ana Strezova. Genotyping of HLA-A, HLA-C and HLA-B Loci with Reverse Line Strip Hybridization in Macedonian Population and Association of HLA Class I Alleles with Spondilitis [MSc thesis]. Maced J Med Sci. 2010; 3(2):188-191.

17. Orne MT. The why and how of a contribution to the literature: a brief communication. Int J Clin Exp Hypn. 1981;29(1):1-4.

18. Trajkov D, Petlichkovski A, Strezova A, Spiroski M. Sixty Years Faculty of Medicine in the Republic of Macedonia (1947-2007). Maced J Med Sci. 2008; 1(1):3-12.

19. Ad Hoc Working Group for Critical Appraisal of the Medical Literature: A proposal for more informative abstracts of clinical articles. Ann Intern Med. 1987; 106: 598-604.

20. Huth EJ. Structured abstracts for papers reporting clinical trials. Ann Intern Med. 1987;106(4):626-7.

21. Altmam DG, Gardner MJ. More informative abstracts. Ann Intern Med. 1987;107(5):790-1.

22. Haynes RB, Mulrow CD, Huth EJ, Altman DG, Gardner MJ. More informative abstracts revisited. Ann Intern Med. 1990;113(1):69-76.

23. International Committee of Medical Journal Editors. Uniform requirements for manuscripts submitted to biomedical journals. JAMA. 1993;269(17):2282-6.

24. Harbourt AM, Knecht LS, Humphreys BL. Structured abstracts in MEDLINE, 1989-1991. Bull Med Libr Assoc. 1995;83(2):190-5.

25. Ripple AM, Mork JG, Knecht LS, Humphreys BL. A retrospective cohort study of structured abstracts in MEDLINE, 1992-2006. J Med Libr Assoc. 2011;99(2):160-3.

26. Nakayama T, Hirai N, Yamazaki S, Naito M. Adoption of structured abstracts by general medical journals and format for a structured abstract. J Med Libr Assoc. 2005;93(2):237-42.

27. McKnight L, Srinivasan P. Categorization of sentence types in medical abstracts. AMIA Annu Symp Proc. 2003:440-4.

28. Pierson DJ. How to write an abstract that will be accepted for presentation at a national meeting. Respir Care. 2004;49(10):120612.

29. Timmer A, Sutherland LR, Hilsden RJ. Development and evaluation of a quality score for abstracts. BMC Med Res Methodol. 2003;3:2. 